\title{
„All New Beginnings are Difficult?”-On Childhood, Politics and Philosophy
}

\section{Barbara Weber (Regensburg)}

?Philosophizing with children? is not an entirely new concept: for example Plato already initiates his philosophical dialogues with young people. And even Kant in his essay What is Orientation in Thinking? (Kant 1991) calls for the early encouragement of reason. The goal is liberation from every form of submission to authority that would destroy an individual?s freedom. For this reason children of ten should already be encouraged to think independently, viagra because this is the only way for reason to become a guidepost or compass leading to freedom (Martens, visit 1999; p. 53).

These are only two of the exemplary ?antecedents.? Concrete implementation in schools of the model ?philosophizing with children? ${ }^{1}$ with its goal of ethical, political, and personal education has existed for nearly 40 years in the USA and for around 35 years in German-speaking countries. During that time a great variety of theoretical, methodological, and practical concepts have been developed from this basic idea. Common to all of them is the desire to promote independent and comprehensive thinking capabilities in children. Included here are not only critical thinking, but also creative and empathetic thinking. A further intention is to support children?s self-assessment and their ability to form opinions autonomously. And not least among the goals, philosophizing with children is often seen as closely related to the support of democratic capabilities.

Many of the concepts developed during those years so far exist only in outline; others by contrast are fully developed theoretical systems with accompanying methods and theme-specific materials. The most fully developed and widely known concepts are Matthew Lipman?s transformation of the classroom group into a community of inquiry, Ekkehard Martens? philosophicaldidactic approach, and the method of Socratic conversation of Leonard Nelson and Gustav Heckmann, practiced chiefly by philosophers and educators in Northern Europe.

But what does it really mean when we speak of ?philosophizing with children?? Martens asks this very question in his book ?Philosophizing with Children? and proclaims: ?Insufficient clarification of the two central concepts ?philosophizing? and ?children? (...) can result in a less-than-desirable practical implementation.? (p. 25). In the following, then, I will briefly discuss Lipman?s own position regarding children, and which ?theory of the child? he bases it on.

\section{Philosophizing with children ? excessive challenge or pedagogical necessity?}

Lipman begins with the basic principle that childhood is just as much part of being human as any other phase of life. He states: ?Moreover, just as the differences between male and female perspectives constitute no insuperable barrier to their being experientially shared, so the differences between child and adult perspectives represent an invitation to the shared experience of human diversity rather than an excuse for intergenerational hostility, repression and guilt.? (Lipman, 1993, p. 143). Of course the argument is often made that children are still incapable of logical or abstract thinking and that ?philosophizing with children? is thus wasted effort. Lipman on the other hand argues that just as in past times pain medications were not given to animals and children in the belief that they really did not feel pain, people today assume that children have no capacity for logical thinking. (Lipman, Sharp, \& Oscanyan, 1977, 1985; p. 408). Often Piaget?s experiments are cited as proof that children are only able from the age of 11 onward to understand logical conclusions or produce them themselves². But Lipman argues, ?? all that Piaget can suggest to educators is that they tailor the child?s education to conform to the phases of his logical development. Yet, as I shall contend later in more detail, even this meager advice is either erroneous or subject to erroneous interpretation. It does not allow for acceleration of education in thinking. And it suggests that because the child thinks concretely in a certain sense in his early years that his instruction during this period should likewise be concrete.

Methodologically this is highly questionable.? (Lipman, 1993, p. 376). Analogously, it would be just as absurd to argue that one should not speak with children because they are not yet able to speak (p. 376). Thus Lipman continues: ?Children are treated as if they were incapable of philosophical deliberation, therefore they behave as if they were incapable of philosophical deliberation.? (p. 378). Lipman?s supposition was confirmed in 1971 by a broad-based test. At that time the California Test of Mental Maturity was administered to a grade level of white and black middle class students. After nine weeks of philosophizing with these children ( 2 x 40 minutes per week) the pilot groups did significantly better ( $\mathrm{p} \%$ o.1): they had achieved a mental advance of 27 months beyond the control groups. And even a few years later the pilot group still scored above the control group with the same statistical significance3 (compare p. 381).

Lipman?s basic attitude to children is thus that for him a. being a child is part of being human, b. children are principally social beings who learn from one another in a democratically ordered community 4 , and c. children are not irrational and therefore in discussions they are not disadvantaged agents, but rather beings who are potentially rational but in need of support And he is convinced that children must learn to think independently before participating actively in the political realm. ?We have got to learn how to teach children to think for themselves if we are to have a democracy worth having.? (Lipman, 2003, p. 35). 
Nevertheless Lipman himself does not offer a ?theory of childhood? that would lead to a specific ethical or pedagogical attitude toward children. And so in the following I would like to examine how we can reconstruct our image or concept of childhood in order to enable both the kind of encounter required by Lipman and also a pedagogically valuable philosophical dialogue with children. Certainly such a representation does not deal with ?final truths? but only with an initial conceptual reflection intended more to develop than to reduce complexity.

\section{Hermeneutics of childhood and the pedagogical moment}

In a 1928 lecture on pedagogy Schleiermacher poses the question whether one should be allowed to use a moment in life as a mere means to an end (Schleiermacher, 1988, p. 46). For often the present moment is sacrificed in the pedagogical act for the sake of a future one. One explains, admonishes, and disciplines children in order to form them into ?reasonable people.? In the background is an image of the child as ?deficient being? or ?incomplete human? who only becomes a ?real person? through education. But the question is, should the generation of the present be allowed to usurp the future?s space by educating children according to preexisting values and norms? Or is not the state of childhood in itself already a political appeal forbidding us to appropriate this space belonging to the future? In the following, in conversation with Hannah Arendt, I will explore to what extent dialogue and children?s education belong ontologically to the sphere of political action and for precisely this reason should not be usurped, because otherwise we rob children of their political and thus genuinely human dimension.

Whereas time was understood by Aristotle as an impersonal arithmos kineseos or numerus motus(Aristotle, Physics, 219B2) (i.e. as number in motion), Heidegger sees it as the existence of man. Or more precisely as man?s being-unto-death (see Heidegger 2001). But with Heidegger too the three temporal ecstasies of past, present and future are developed from within me, myself. And so my time remains synchronous: my time and my freedom are sovereign.

In her book Vita activa (The Human Condition, 1958) Arendt divides human activity into three forms: labor, work, and action. For Arendt these three activities correspond to different temporal modes, on the one hand natural-cyclical time and on the other linear-human time (p. 28). Cyclical time represents the undifferentiated becoming and dying away of the natural world. This is where labor occurs as the lowest human activity. Arendt understands labor to be constant production and consumption at the level of mere survival. It thus remains in the private sphere since it is only focused on preservation of the body?s economy.

But within this constant flux we create a modicum of permanence and continuity through producing objects (the middle type of activity in Arendt). A chair, a table, or even a house can often outlast a human lifespan. The possibility and purpose of this world of manufactured objects, then, is to create an enduring physical home for humans surrounded by the cyclical time of nature and labor. Due to its existence, children are always already born into an existent world: into a house, a city, an established environment. Also connected to this manufactured world is the world of culture, i.e. the traditional uses of tools and objects of daily life. But both labor and manufacture belong to the private realm and in Arendt?s view do not constitute what is intrinsically human.

The highest activity is action. It belongs to the public realm and in contrast to labor and work, occurs in a world shared with others, and thus in a web of words and deeds. Action takes place in linear time, which is time?s specifically human form. Through the singularity and unexpectedness of action man breaks out of the cyclical time of nature and tradition. The opportunity to begin anew is the human birthright and is central to Arendt?s anthropology: ?Because they are initium, newcomers and beginners by virtue of birth, men take initiative, are prompted into action.? (p. 177). Devoid of all history, the first cry is a free act of being, at once opening up all realms of possibility. Although Arendt assigns even child-rearing and all of women?s traditional tasks to the private sphere, childhood, due to its ontological essence, stands out from the private sphere, for the new beginning of man is based in childhood. Or to say it another way: the birth of a child is in itself a political act because the new dares to enter into an already existing world. Birth breaks through the cycle of nature because a beginning is set into the world.

Thus not only bearing children but also raising them is potentially a political act: if children are seamlessly bonded to the past the explosive political force of their existence seeps away. The future?s space is usurped by the past. On the other hand, a political sphere arises when people are born into an existing world which remains open to niches of novelty and futurity, making space for beginnings (i. e. allowing children to be children).

This latter thought in particular can be expanded by the political dimension of pardon and promise in Arendt: in the generational encounter we bequeath our past as tradition to the children so that they are born into an already existing world. The ?gift? children bring to us, in turn, is their time and their new beginning, which releases us from the errors of the past. This dialogue between that is new and tradition can also be called a hermeneutical appropriation of the effects of one?s history (an example would be such fatal historical occurrences as the Holocaust or the current conflicts between Israel and the Palestinians. The current generation can only free itself with difficulty because of its own involvement. Children by contrast are still open and can dare to make a new beginning insofar as this is not prevented by the previous generation (by propaganda or manipulation).

On the one hand children learn through the experiences of adults, on the other their new interpretation of the world resembles a departure into the future. In this way children provide an original way of approaching the world that neither can nor should be 
predetermined by adults. Examples of such new interpretations could include both the world of ordinary objects (such as a chair transformed into a house or hiding place) and the reconstitution of political events (for example liberation from hatred or resentment). The two modes of binding and liberation can also be related to Arendt?s two ?remedies against the irreversibility of action.? ?The possible redemption from the predicament of irreversibility? of being unable to undo what one has done though one did not, and could not, have known what he was doing? is the faculty of forgiving. The remedy for unpredictability, for the chaotic uncertainty of the future, is contained in the faculty to make and to keep promises.? (p. 237). Only when we leave open a space in the future do children free us from past deeds because they are in themselves a new beginning in history. The children?s time inserts itself into ours, appropriates something there and carries it on into an open unoccupied future space. In this way children are equivalent to a generational forgiving. At the same time children are our promise, our hope that things will be ?better? and will ?go on.?

In contrast to Arendt, for whom linear time may indeed belong to the intersubjective realm of action but yet always remains my time, Emmanuel Lévinas questions the encounter between two sovereign times. Here it is the ethical dimension which derives from the circumstance that the Other has a future, or in other words, is free. Thus Lévinas turns his gaze to that place where an Other (the child) intrudes into my time as a stranger. ?The future is that which can?t be grasped, but which attacks us and seizes hold of us. The future is the Other. [?] The face-to-face situation is the primal revelation of time; the encroaching of presence on the future is not the act of a lone subject, but the intersubjective relationship.? (Lévinas, 1989, pp. 48-51). Wherever another time inserts itself into mine a rupture occurs: the alien time does not submit to me; instead its freedom gets in my way. (Lévinas, 1993, p. 438). Its presence forces me to assume responsibility for what has happened. Its gaze is my visibility: there is no escape. I am its hostage and must surrender. This gaze does not tolerate the mere appropriation of my past which already long ago ceased to be mine, but subordinates me to this present, to the presence of the Other, to whom I as a person must answer. ?Summons to identity because of the response of responsibility, where nobody can be substituted without becoming guilty.? (Lévinas, 1998, p. 311). History is no object we take upon ourselves. History is an imperative for the future which each one answers for in his or her own way.

This ?diachronicity? takes place in each encounter with another person, but finds its fulfillment in parenthood. For the child is to a remarkable degree a stranger. Lévinas asserts: ?The son is me, a stranger to myself.? (1993, p. 391, in original: ?[?] il est moi. C?est moi, étranger ? soi.?). Through this affirmation of alien time a free child appears ex nihilo. ?As my future and not my future, as a possibility I am entitled to but which is also a possibility of the Other.? (p. 392). But since the child is neither my work nor my creation, my relationship to it cannot be described in categories of knowledge, competency, or possession.

By learning a culture?s activities and how to use its objects children carry on our lives and subjectivities. The future of a parent, however, is not the future of the child. Each child is a break with history. As a result, children assume responsibility when it is already too late for us. Children take on history in the sense of a narrative about where they came from, who they are, and where they are going. But at the same time this active appropriation breaks with the original meaning. History becomes discontinuous. If this space for the new is usurped there is no end to the entanglements of history: ?Transcendence is time and moves towards the Other. But the Other is not the destination; he does not stop the movement of desire. The Other, which desire craves, is still desire; the transcendence transcends towards the person who transcends ? this is the adventure of parenthood, the transubstantiation; it allows us to transcend the mere renewing of the possible within the unavoidable aging process.? (p. 394). For the dialogue between generations this means that in the encounter with our children we must stand up to another time, an unknown future, and at the same time we must answer for the past in the present.

But very often educators do not engage in a horizontal dialogue with children but rather in a vertical one. Adults explain the world to the child; they give instructions or ask questions whose answers they already think they know5.

Bernhard Waldenfels and Käte Meyer-Drawe describe the dialogue between educators and children as follows: ?The separation between the own and the Other works better the more our dialogue [with children] remains within a reproductive and applicative structure and is constrained to a repetition and handing down of a prefabricated meaning.? (Mayer-Drawe \& Waldenfels, 1988, p. 275). Such a reproductive pedagogy denies the political dimension of childhood.

\section{Summary: philosophizing with children as a contemporary pedagogy}

For precisely this reason philosophical dialogue is recommended as a horizontal encounter which actively engages children in the history of what has happened and at the same time leaves open the future?s space through a perplexed, critical, and questioning approach. Especially in discussions of philosophical questions no communicative pattern or thought schema and no pre-ordained content exists. The role of possessing knowledge carries no advantage, so in a shared creation of meaning and values it is the adults who submit themselves most to the otherness and novelty of children?s thinking. Waldenfels and MeyerDrawe describe it similarly: ?The separation between the own and the Other works less well the more productive the discourse is and the more it contributes to creating new terms of understanding and changing standards instead of merely applying them.? (p. 275). In a conversation of concern to both parties in which meaning is created anew a chiasm is created between child and adult. That is the interface along which present and future intersect. Adults tie the children to the past through transmission of tradition, children loosen adult bonds to this past through their new beginning and?metaphorically speaking?cast their ?hooks of hope? into a new future. 
This kind of confrontation in philosophical conversation can be confusing or disturbing; Matthews himself describes how he was often overwhelmed by the philosophical conversation on fear with children from the ghetto (Matthews, 1999, p. 14). But it is only in such an encounter, in which the Other startles and confuses us, that children become equally valuable although not similar partners. Here the pedagogue?consider here the etymological meaning: Greek paid-agogós, or one who guides the child on its way home?must relinquish his ?leadership position? and become a trusted ?companion? or a ?pathfinder? on a road that is known to neither of them but which both will now travel for awhile together. In the pedagogical encounter only this kind of approach realizes the political dimension of childhood. Childhood is not just a ?pre-political level of humanity,? but the precondition for the appearance of any political sphere at all, that is, a locus of free action, of hope, and of futurity.

\section{References}

Arendt, H. (1959). The Human Condition. Chicago: University of Chicago Press.

Aristotle (1999). Physics. Tr. with comm. by D. Graham. Oxford: Clarendon Press.

Heidegger, M. (1999). Being and Time. Tr. by J. Macquarrie. London: Blackwell.

Kant, I. (1991). What is Orientation in Thinking? In: H. Reiss (ed.), Kant. Political Writings. Tr. by H.B. Nisbet. 2nd, enlarged edition. Cambridge: Cambridge University Press, pp. 237-249.

Lévinas, E. (1992, 1998). Outside of Being. Quotations in this chapter from the German version: Jenseits des Seins oder anders als Sein geschieht. Tr. by T. Wiemer. Freiburg/Br. \& Munich: Alber.

Lévinas, E. (1969). Totality and Infinity. Pittsburgh: Duquesne University Press. Quotations in this chapter from the German version: Totalität und Unendlichkeit (1993). Tr. by W.N. Krewani. Freiburg/Br. \& Munich: Alber.

Lévinas, E. (1984). Time and the Other. Quotations in this chapter from the German version: Die Zeit und der Andere. Hamburg: Meiner.

Lipman, M., Sharp, A.M., \& and Oscanyan, F.S. (1977, 1985). Ethical Inquiry. 2nd edition. New Jersey: IAPC, and IAPC \& UPA.

Lipman, M. (1993). Thinking, Children, Education. Dubuque (Iowa): Kendall and Hunt.

Lipman, M. (2003). Thinking in Education. Cambridge: Cambridge University Press.

Martens, E. (1999). Philosophieren mit Kindern. Stuttgart: Philipp Reclam Verlag

Matthews, G. B. (1999). Socratic Perplexity and the Nature of Philosophy. Oxford: Oxford University Press.

Meyer-Drawe, K., \& Waldenfels, B. (1988). Das Kind als Fremder (=Child as a Stranger). Vierteljahresschrift für wiss. Pädagogik, No. 46.

Schleiermacher, F. (1988). Pädagogische Schriften (=Pedagogical Writings). 2nd edition. Vol. 1. E. Weniger (ed.). Düsseldorf \& Munich: Kuepper.

1. In the following the concept ?philosophizing with children? is used exclusively. It subsumes all approaches that are based explicitly on philosophical contents, salve methods, or approaches in order to support children in their thinking, feeling, and/or actions. this is an attempt to avoid conceptual confusion, because in many approaches distinctions are made at times which are not exactly worked out. Examples are the concepts ?Philosophy for Children,? ?Children Philosophize,? ?Reflecting with Children,? or ?Children?s Philosophy.? (context)

2. This is of course a very abbreviated interpretation of Piaget?s detailed investigations and does not really coincide with Piaget?s own approach. (context)

3. Such a methodological construction of the concept philosophy is, of course, problematic, since philosophical conversations do not exhaust themselves in teaching children ?right thinking.? (context)

4. This refers to John Dewey?s concept of ?Democracy as a way of life?. (context)

5. See Matthews 1999: In this context Matthews points out a misunderstanding of the Socratic method, because often it is so understood as if one would lead a pupil to the ?right answer,? which the pedagogue already knows, by asking questions. (context) 